JAMP: Jurnal Adminitrasi dan Manajemen Pendidikan

Volume 1 Nomor 4 Desember 2018, Hal : 440-447

Tersedia Online di http://journal2.um.ac.id/index.php/jamp/

ISSN 2615-8574 (online)

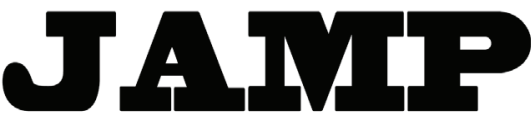

\title{
KEPRIBADIAN YANG BAIK UNTUK KEEFEKTIFAN KEPEMIMPINAN KEPALA SEKOLAH
}

\author{
Vonny Angeli Sudharta \\ Ibrahim Bafadal \\ Sultoni \\ vonnysudharta@gmail.com \\ Universitas Negeri Malang, J1 Semarang 5 Malang 65145
}

\begin{abstract}
Personality is inherent in individuals who can then be influenced by the environment, in which personality leadership has various elements. In this study the aim is to find out (1) the character possessed by the principal, (2) the integrity of the principal's personality, (3) the desire of the principal in self-development, (4) openness to the implementation of duties and functions in carrying out the leadership of the principal, (5) Self-control of the principal in overcoming problems in SMPN 11 and SMPN 18 Malang. Where this is in order to determine the effectiveness of the principal's leadership. The method used in this study is qualitative descriptive using multi-site design. Data collection techniques used are interviews, observation and documentation. The subject of this study was the Head of SMPN 11 and SMPN 18 Malang, with the source of the principal, vice principal, administration, teachers and students. Data analysis is done by reducing, presenting data, drawing conclusions and verification. The results of this study are, (1) The principal has good behavior in accordance with the indicators of the principal's personality competency. (2) The Head of SMPN 11 and 18 Malang has good personality integrity which is shown by the attitude of honesty, fairness, discipline, etc. (3) In achieving the goals of the principal make the program planned carefully and implemented as well as possible so that each goal is achieved. (4) The principal also shows openness in carrying out all the duties of the principal, both opinions and concerns for all school members. (5) The principal has good self-control in problem solving.
\end{abstract}

Keywords: personality, effectiveness of leadership, headmaster

Abstrak: Kepribadian merupakan sifat yang melekat pada individu yang kemudian dapat dipengaruhi oleh lingkungan, dimana dalam kepemimpinan kepribadian memiliki berbagai unsur. Dalam penelitian ini memiliki tujuan untuk mengetahui (1) Akhlak yang dimiliki kepala sekolah, (2) Integritas kepribadian kepala sekolah, (3) Keinginan kepala sekolah dalam pengembangan diri, (4) Keterbukaan terhadap pelaksanaan tugas dan fungsi dalam pelaksanaan kepemimpinan kepala sekolah, (5) Pengendalian diri kepala sekolah dalam mengatasi permasalahan di SMPN 11 dan SMPN 18 Malang. Dimana hal tersebut guna mengetahui keefektifan kepemimpinan kepala sekolah. Metode yang digunakan peneliti dalam penelitian ini yaitu kualitatif deskriptif dengan menggunakan rancangan multi situs. Teknik pengumpulan data yang digunakan yaitu wawancara, observasi dan dokumentasi. Subjek penelitian ini adalah Kepala SMPN 11 dan SMPN 18 Malang, dengan sumber kepala sekolah, wakil kepala sekolah, tata usaha, guru dan siswa. Analisa data dilakukan dengan cara reduksi, penyajian data, penarikan simpulan dan verifikasi. Hasil dari penelitian ini yaitu, (1) Kepala sekolah memiliki perilaku yang baik sesuai dengan indikator kompetensi kepribadian kepala sekolah. (2) Kepala SMPN 11 dan 18 Malang memiliki integritas kepribadian baik yang ditunjukkan dengan sikap kejujuran, keadilan, disiplin, dll. (3) Dalam pencapaian tujuan kepala sekolah membuat program yang sudah direncanakan matangmatang dan dilaksanakan sebaik-baiknya sehingga tiap tujuan tercapai. (4) Kepala sekolah juga menunjukan keterbukaan dalam melaksanakan segala tupoksi kepala sekolah, baik 


\begin{abstract}
pendapat maupun hal kepedulian terhadap semua anggota sekolah. (5) Kepala sekolah
\end{abstract} memiliki pengendalian diri yang baik dalam pemecahan masalah.

Kata Kunci: kepribadian, keefektifan kepemimpinan, kepala sekolah

Pemimpin merupakan kunci dari sebuah organisasi, seorang pemimpin dianggap penting dalam suatu pendidikan, sebab pemimpin harus mampu untuk menggerakkan semua komponen, sehingga tujuan pendidikan yang telah direncanakan dapat tercapai secara efektif dan efisien. Seperti yang dijelaskan Koesmintardjo (dalam Gunawan \& Benty, 2017) bahwa pemimpin efektif adalah bersumber dari kepribadian pemimpin itu sendiri sebagai seorang insan. Pendapat tersebut membuktikan bahwa hal yang mempengaruhi dalam kepemimpinan kepala sekolah adalah kepribadiannya sendiri. Sebagaimana yang dicantumkan dalam Peraturan Menteri Pendidikan Nasional (Permendiknas) Republik Indonesi Nomor 13 tahun 2007 tentang Standar Kepala Sekolah/Madrasah disebutkan bahwa kepala sekolah harus memiliki 5 kompetensi yaitu kepribadian, manajerial, kewirausahaan, supervisi dan sosial.

Kepribadian menurut Yulk (2001) yaitu "Personality traits are considered especially relevant to successful leadership...”. Yang memiliki arti bahwa karakter dari kepribadian sangat relevan dengan kesuksesan kepemimpinan. Kompetensi kepribadian sendiri merupakan perpaduan dari pengetahuan, nilai, keterampilan dan sikap yang direfleksikan dalam kebiasaan berfikir dan bertindak menurut Ditjen PMPTK (dalam Arifin, 2015). Harianto (2017) menjelaskan bahwa gelaran lomba evaluasi kinerja kepala sekolah pada Kamis 22 Desember 2016. Menobatkan Bapak Sutikno

Kepribadian merupakan istilah dari bahasa Inggris yaitu personality. Istilah tersebut berasal dari bahasa Yunani, yaitu pesona, yang berarti topeng dan pesonare,yang artinya menembus (Praja, 2012). Heuken (dalam Pradja, 2012) menjelaskan pula mengenai kepribadian adalah pola menyeluruh semua kemampuan, perbuatan, serta kebiasaan seseorang, baik jasmani, mental, rohani, emosional maupun sosial. Dari pendapat di atas dapat disimpulkan bahwa kepribadian merupakan perilaku dari setiap individu yang dipengaruhi oleh sikap dari dalam diri yang merupakan identitas pribadi setiap individu.

Suhardiman (2012) juga menjabarkan indikator kompetensi kepribadian yang dimiliki kepala sekolah sebagai berikut,

Tabel 2.1 Indikator Kepribadian Kepala Sekolah

\begin{tabular}{lll}
\hline No & \multicolumn{1}{c}{ Indikator } & \multicolumn{1}{c}{ Sub Indikator } \\
\hline 1. & Mengembangkan budaya \\
dan tradisi, dan menjadi & (a) melaksanakan ibadah sesuai kepercayaan yang dianutnya; \\
teladan akhlak mulia & (b) sikap dan perilaku menjadi keteladanan bagi warga \\
& sekolah; \\
& (c) memiliki empati terhadap masalah yang dihadapi warga \\
& sekolah; \\
& (d) mampu mengembangkan budaya salam, senyum, sapa, \\
& sopan, santun,; \\
& (e) adanya pengakuan dari warga sekolah terhadap \\
& keteladannya \\
\hline 2. & (a) memiliki kejujuran dalam melaksanakan TUPOKSI; \\
kepala sekolah/madrasah & (b) memiliki ketulusan dalam melaksanakan TUPOKSI; \\
dengan sikap kejujuran, & (c) memiliki komitmen yang tinggi dalam melaksanakan \\
ketulusan, komitmen dan & TUPOKSI; \\
integritas & (d) memiliki integritas yang tinggi dalam melaksanakan \\
& TUPOKSI \\
\hline
\end{tabular}




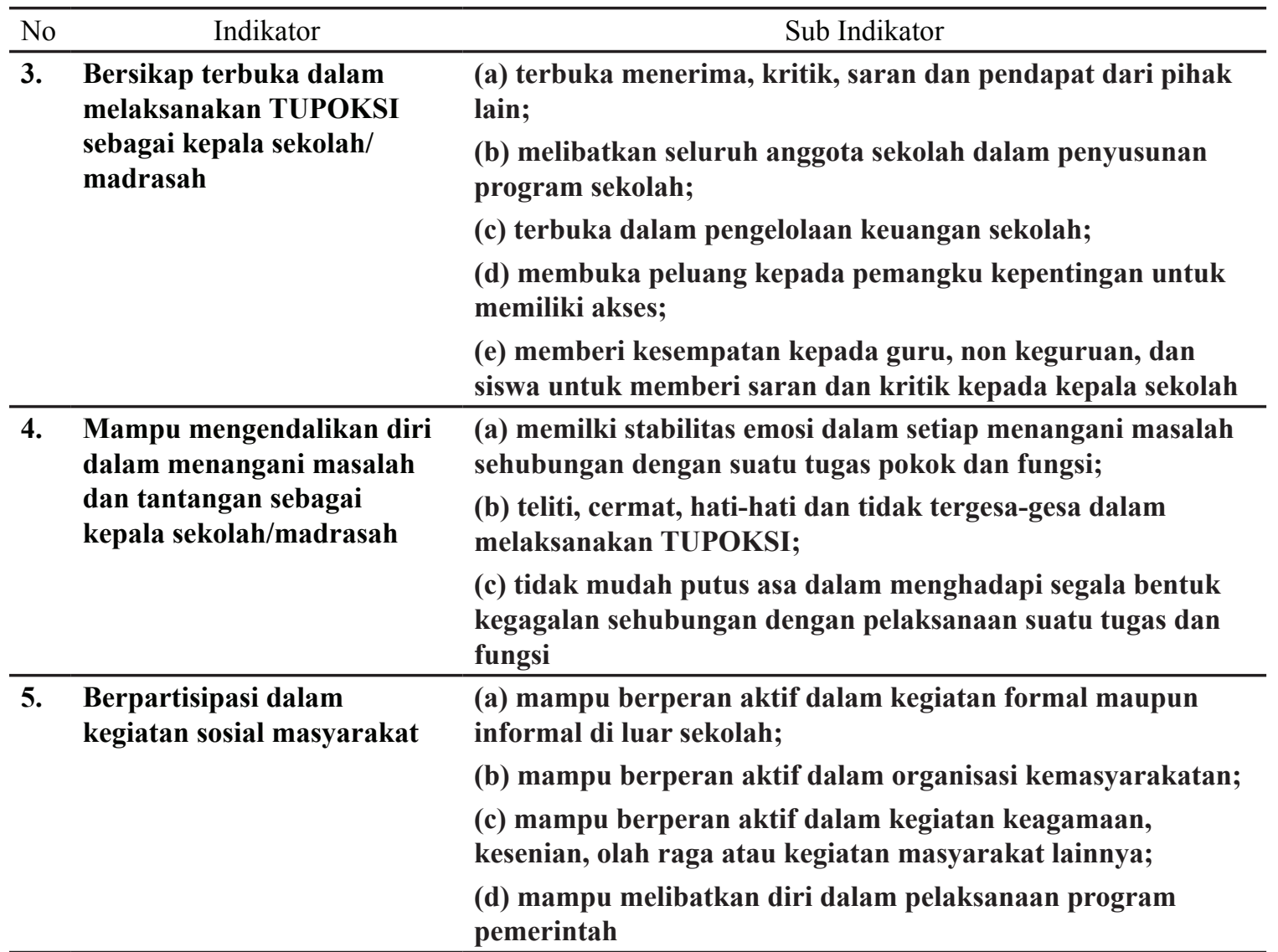

6. Tanggap dan peduli terhadap kepentingan orang lain atau kelompok

(a) mampu mencari persoalan dari lingkungan sekolah (berperan sebagai problem finder);

(b) mampu dan kreatif menawarkan solusi (sebagai problem solver);

(c) mampu melibatkan tokoh agama, masyarakat dan pemerintah dalam memecahkan masalah lembaga;

(d) mampu bersikap objektif/tidak memihak dalam mengatasi konflik internal sekolah;

(e) mampu bersikap simpati terhadap orang lain;

(f) mampu bersikap empati terhadap orang lain

\begin{tabular}{lll}
\hline 7. $\begin{array}{l}\text { Mengembangkan dan } \\
\text { mengelola hubungan sekolah/ }\end{array}$ & $\begin{array}{l}\text { (a) mampu bekerja sama dengan atasan bagi pengembangan } \\
\text { dan kemajuan sekolah; }\end{array}$ \\
$\begin{array}{l}\text { luar sekolah/madrasah } \\
\text { dalam rangka mendapatkan } \\
\text { dukungan ide, sumber }\end{array}$ & $\begin{array}{l}\text { (b) mampu bekerja sama dengan guru, staf, komite sekolah; } \\
\text { belajar dan pembiayaan } \\
\text { sekolah/madrasah }\end{array}$ & $\begin{array}{l}\text { (d) mampu bekerja sama dengan dewan pendidikan kota/ } \\
\text { kabupaten dan stakeholder sekolah }\end{array}$ \\
\hline
\end{tabular}

Kepribadian menjadi landasan bagi kepemimpinan, karena kepribadian adalah serangkaian karakteristik yang dinamis dan terorganisasi yang dimiliki oleh seorang pemimpin yang secara unik dapat mempengaruhi kognisi, motivasi, tingkah laku kepemimpian orang tersebut (Hermanto, 2012).

Kompetensi kepribadian yang baik menurut Sudrajat (dalam Makawimbang, 2012) adalah

1) Memiliki komponen integritas kepribadian yang kental sebagai pemimpin yang ditunjukkan dengan: a) Memiliki konsisten dalam berpikir, bersikap, berucap, dan berbuat dalam setiap melaksanakan suatu tugas pokok dan fungsi, b) Memiliki etoskerja atau komitmen yang tinggi dalam melaksanakan 
suatu TUPOKSI, c) Tegas dalam mengambil keputusan dan tindakan sehubungan dengan pelaksanaan suatu TUPOKSI, d) Disiplin dalam melaksanakan TUPOKSI; 2) Memiliki keinginan yang kuat dalam mengembangkan diri sebagai kepala sekolah yang ditunjukkan dengan: a) Memiliki rasa keingin tahuan yang tinggi terhadap praktik baru, kebijakan, teori, sehubungan dengan pelaksanaan suatu TUPOKSI, b) Mampu mengembangkan diri secara mandiri sebagai upaya pemenuhan rasa keingintahuannya terhadap kebijakan, teori, praktik baru sehubungan dengan pelaksanaan suatu TUPOKSI, c) Bersikap terbuka dalam melaksanakan TUPOKSI, d) Selalu untuk menginformasikan secara transparan dan profesional kepada orang lain atas segala rencana, proses pelaksanaan, dan keefektifan, kelebihan dan kekurangan pelaksanaan suatu TUPOKSI, e) Terbuka atas kritik dan saran yang disampaikan oleh atasan, teman sejawat, bawahan, dan pihak lain atas pelaksanaan TUPOKSI; 3) Mampu mengendalikan diri dalam menyelesaikan masalah sebagai kepala sekolah dengan sikap yang ditunjukkan dengan: a) Memiliki kesetabilan emosi dalam setiap menghadapi masalah sehubungan dengan suatu TUPOKSI, b) Teliti, cermat, hati-hati, dan tidak tergesa-gesa dalam melaksanakan suatu TUPOKSI, c) Tidak mudah putus asa ketika menghadapi segala bentuk kegagalan sehubungan dengan pelaksanaan suatu TUPOKSI; 4) Memiliki bakat dan minat jabatan sebgai pemimpin pendidikan yang ditunjukkan dengan memiliki minat jabatan untuk menjadi kepala sekolah yang efektif dan memiliki jiwa kepemimpinan yang sesuai dengan kebutuhan sekolah.

Kepemimpinan efektif menurut Anwar (dalam Benty \& Gunawan, 2017) adalah kepemimpinan yang dapat melaksanakan setiap fungsi untuk mencapai tujuan pendidikan yang maupun menciptakan iklim sekolah yang kondusif. Efektivitas kepemimpinan kepala sekolah tergantung pada kemampuan kerjasama dengan guru dan staf, serta kemampuan mengendalikan anggaran sekolah, pengembangan staf, penjadwalan, pengembangan kurikulum, paedagogi, dan assessmen (Putri \& Sundari, 2012).

Gunawan Dan Benty (dalam Sudharta, 2017) juga berpendapat bahwa Good leader is good person, artinya pemimpin yang baik adalah berasal dari orang yang memiliki kepribadian baik pula. Jadi dapat disimpulkan kepemimpinan merupakan kemampuan mempengaruhi individu atau orang lain, melalui komunikasi secara langsung maupun tidak langsung dengan maksud mengerakan setiap individu dengan pengertian, dan senang hati bersedia mengikuti perintah pemimpin tersebut sehingga dapat mencapai tujuan.

\section{METODE}

Penelitian dilakukan menggunakan pendekatan kualitatif deskriptif. Jenis penelitian yang digunakan peneliti yaitu multi situs, penelitian ini dilakukan kepada 2 SMP Negeri di Kota Malang yaitu SMPN 11 Malang dan SMPN 18 Malang. Dalam hal ini peneliti berperan sebagai instrumen kunci yang hasilnya nanti lebih menekankan makna, menurut Sugiono (2012). Teknik pengumpulan data dalam penelitian ini yaitu wawancara semi terstruktur merupakan gabungan dari wawancara terstruktur dengan wawancara tidak terstruktur yang digunakan secara simultan (Ulfatin, 2015), pengamatan/ observasi dan dokumentasi.

Sumber data dari penelitian ini yaitu dari SMPN 11 Malang ada 4 orang yaitu Bapak Sutikno selaku kepala SMPN 11 Malang, Ibu Yuniati selaku bendahara BOS dan guru IPA, Ibu Rohma guru PPKN, Ibu Siti selaku TU di SMPN 11 Malang, papan-papan informasi mengenai dana BOS, serta piagam penghargaan yang didapat kepala sekolah. Sedangkan sumber dari SMPN 18 Malang yaitu Bapak Sa'i selaku wakil kepala sekolah bidang sarana dan prasarana, Bapak Joni Wakil Kepala Sekolah Bidang Kurikulum, Ibu Dwi selaku Wakil Kepala Sekolah Bidang Kesiswaan, Andhita Neisha dan Reza Putra Ramadani selaku siswa kelas 8 .

Peneliti menggunakan proses analisis data dari Miles, dkk., (dalam Ulfatin, 2013) yang terdiri dari reduksi data, penyajian data, dan verifikasi. Penelitian menggunakan pegecekan keabsahan data untuk menguji tingkat kebenaran data yang diteliti, dengan cara triangulasi baik sumber maupun metode, intensitas pengamatan, kecukupan bahan referensi, dan member cek. 


\section{HASIL}

\section{Akhlak yang dapat Diteladani dari Kepala Sekolah di SMPN 11 dan SMPN 18 Malang}

Akhlak yang dimiliki oleh kepala sekolah hampir semua dapat ditiru oleh semua warga sekolah, dalam hal ini kepala sekolah dapat menjadi teladan bagi guru maupun siswa. Akhlak baik yang ditunjukkan kepala sekolah seperti sopan, ramah kepada sesama, memiliki jiwa kekerabatan atau sosial yang tinggi, santun dan religius.

Dari akhlak yang ditunjukan oleh kepala sekolah, hal tersebut membuat kesan baik dari kepala sekolah sendiri, warga sekolah juga sangat setuju bahwa kepala sekolah dapat menjadi teladan bagi semuanya. Dengan akhlak yang baik, kepala sekolah dapat menciptakan hubungan yang baik pula terhadap semua warga sekolah baik guru, siswa, staf maupun orang tua peserta didik. Dimana hal tersebut dapat menunjang pencapaian tujuan secara efektif dan efisien karena semua komponen dapat bekerjasama.

\section{Integritas Kepemimpinan Kepala Sekolah di SMPN 11 dan SMPN 18 Malang}

Integritas kepemimpinan kepala sekolah ditunjukkan dengan sikap kejujuran, ketertiban, ketegasan, bijaksana dan dapat memotivasi semua anggota sekolah, baik guru, staf maupun siswa. Kejujuran dapat dilihat dari cara pengelolahan dana yang dimiliki sekolah, selain itu ketertiban baik dalam hal administrasi, ketertiban personil sekolah maupun penataan sekolah ditunjukkan dengan memberikan pelatihan mengenai administrasi sekolah, memberikan contoh ketertiban misal dalam ketepatan waktu dan tanggung jawab mengajar setiap guru, kebijaksanaan dilihat dalam tugas yang diberikan kepala sekolah kepada setiap bawahan yang pasti akan melihat kemampuan dari setiap individu

\section{Keinginan Kepala Sekolah Dalam Pengembangan Diri di SMPN 11 dan SMPN 18 Malang.}

Pengembangan diri yang dilakukan oleh kepala SMPN 11 Malang yaitu dengan membaca buku, mencari bahan di internet, belajar dari youtube, pelatihan, workshop dan bertukar pikiran terhadap sesama kepala sekolah. Tidak berbeda jauh dengan Kepala SMPN 11, Kepala SMPN 18 Malang juga senantiasa melakukan pengembangan diri. Pengembangan diri yang dilakukan Kepala SMPN 18 Malang yaitu dengan mendatangkan pembicara ahli dari luar dengan memberikan materi yang berbobot, berbagi pengalaman dengan sekolah-sekolah binaan lain, pelatihan dll.

\section{Keterbukaan Kepala Sekolah dalam Pelaksanaan Tugas dan Fungsi sebagai Pemimpin di SMPN 11 dan SMPN 18 Malang}

Keterbukaan kepala sekolah dalam pelaksanaan tugas pokok dan fungsi dapat dilihat dari cara kepala sekolah dalam melaksanakan berbagai tugas, contohnya kepala sekolah menerima segala bentuk kritik dan saran yang disampaikan oleh semua warga sekolah. Penyampaian kritik dan saran yang membangun kepada kepala sekolah dapat dilakukan oleh siapapun baik siswa, guru, orang tua siswa, staf dan wakil kepala sekoah. Penyampaian dapat dilakukan secara langsung dalam rapat maupun saat bertatap muka, dan dapat dilakukan secara tidak langsung bisa melalui wakil kepala sekolah maupun guru. Kemudian dari kritik dan saran tersebut dipertimbangkan, jika dari kritikan ada yang tidak sesuai dengan pendapat kepala sekolah, artinya menurut kepala sekolah salah, maka tidak akan dilakukan dan mencari jalan terbaik, namun kritik dan saran tersebut akan tetap kepada semua personil sekolah.

\section{Pengendalikan Diri Kepala Sekolah di SMPN 11 dan SMPN 18 Malang dalam Menghadapi Masalah}

Perilaku pengendalian diri kepala sekolah ditunjukkan dalam cara kepala sekolah menangani permasalahan baik kecil, besar, individu atau kelompok. Perilaku yang dapat diamati dalam penyelesaian masalah yaitu emosi pemimpin dan cara pemimpin menyelesaikan masalah. Dalam pengendalian diri kepala SMP Negeri 11 dan SMP Negeri 18 Malang, memiliki emosi yang stabil, tidak mudah memutuskan permasalahan, tidak tergesa-gesa, melainkan melihat akar permasalahan terlebih dahulu dan kemudian dilihat kelompok permasalahan, umum atau individu. Jika bersifat umum maka akan melibatkan banyak pihak dengan diadakan rapat, sedangkan untuk masalah individu akan melibatkan yang bersangkutan 
saja. Selain itu kepala sekolah juga bukan orang yang mudah putus asa, dengan semangat dari lingkungan dan dari dalam diri pribadi, kepala sekolah selalu berusaha untuk mewujudkan apa yang menjadi tujuan. Hasil temuan secara keseluruhan dapat digambarkan dalam diagram aktif, seperti pada gambar dibawah ini

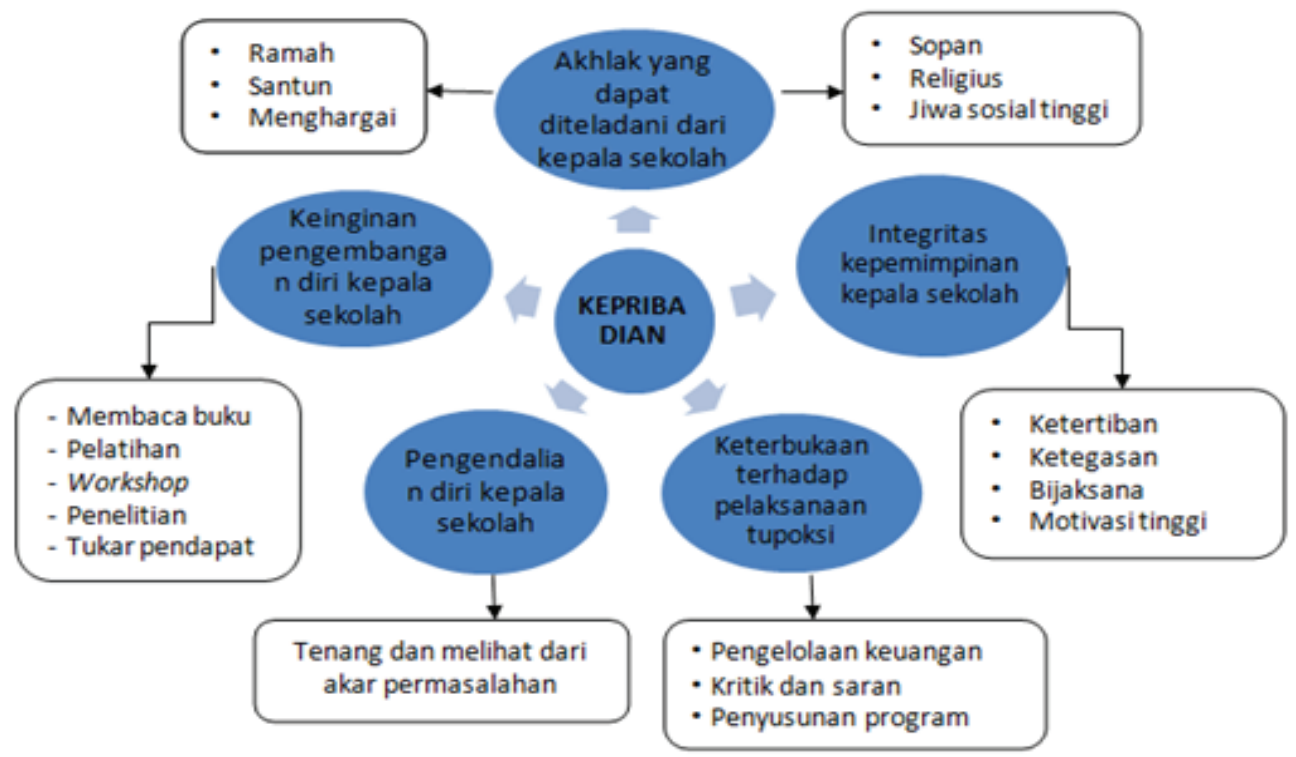

\section{PEMBAHASAN}

\section{Akhlak yang Dapat Diteladani dari Kepala Sekolah di SMPN 11 dan SMPN 18 Malang}

Akhlak yang ditampilkan oleh kepala sekolah hampir semua warga sekolah sangat setuju untuk dapat dijadikan teladan. Sesuai dengan pendapat Jaenudin (2012) bahwa kepribadian dapat mempengaruhi keefektifan kepemimpinan kepala sekolah karena dari kepribadian tersebut dapat dilihat dari intektual, hubungan sosial, emosional, keadaan fisik, imajinasi, dan kekuatan jasmani.

Hasil penelitian dapat disimpulkan bahwa akhlak yang ditampilkan kepala sekolah baik Kepala SMPN 18 Malang maupun SMPN 11 Malang memliki kesamaan yaitu ramah, santun, religius, selalu menghargai semua anggota sekolah, dan hal yang membedakan antara kepala sekolah ini adalah Kepala SMPN 11 Malang lebih sering tersenyum saat berpapasan dengan yang lain, sedangkan Kepala SMPN 18 Malang lebih terkesan wajah tegas. Namun hal tersebut tidak berpengaruh kepada keadilan dan ketegasan dalam mengambil keputusan.

Dapat disimpulkan bahwa kepala sekolah memiliki perilaku yang baik sesuai dengan indikator kompetensi kepribadian kepala sekolah, sehingga dapat menggerakkan semua bawahan untuk mencapai tujuan setiap program yang telah direncanakan.

\section{Integritas Kepemimpinan Kepala Sekolah Di SMPN 11 dan SMPN 18 Malang}

Pribadi yang dimiki Kepala Sekolah SMPN 18 dan SMPN 11 Malang yaitu sama-sama memiliki pribadi yang selalu bersemangat, jujur, disiplin, seorang yang selalu memotivasi bawahan dan tidak mudah putus asa. Seperti pendapat Arief (dalam Lukman, 2016) yang menjelaskan bahwa

Integritas kepala sekolah yaitu menyangkut sifat, mutu dan keadaan yang menunjukkan keutuhan sehingga memiliki potensi dan kemampuan yang memancarkan kewibawaan dan kejujuran. Moralitas menyangkut budi pekerti, akhlak, susila, ajaran tentang baik dan buruk, segala sesuatu yang berhubungan dengan etika dan adat sopan santun

Dalam wawancara, kepala sekolah menyampaikan bahwa integritas kepribadian sangatlah penting, dimana kepala sekolah dalam bekerja mengutamakan, satu, kejujuran / transparan dalam melakasanakan tugas. Kedua, mengutamakan pelayanan, sebaik-baiknya. Ketiga, mengutamakan kenyamanan, mengutamakan perasaan nyaman pegawai, dan bersungguh-sungguh. Kelima, semangat dalam bekerja. 
Dapat diartikan bahwa kepala sekolah memiliki integritas kepribadian yang ditunjukkan dengan sikap kejujuran, keadilan, disiplin, dll. Sehingga dapat menciptakan kesan kewibawaan sehingga kepala sekolah dapat bekerjasama dengan semua anggota sekolah dengan baik.

\section{Keinginan Kepala Sekolah dalam Pengembangan Diri di SMPN 11 dan SMPN 18 Malang}

Pengembangan diri yang dilakukan Kepala SMPN 11 Malang ditujukkan dengan, selalu mengikuti pelatihan, membaca, berdiskusi dengan kepala sekolah lain, kemudian untuk Kepala SMPN 18 Malang pengembangan diri dilakukan dengan mendatangkan pembicara, melakukan workshop dan kunjungan antar sekolah untuk berbagi ilmu. Arief (dalam Lukman, 2016) menjelaskan bahwa

Etika dan moralitas yang harus dimiliki pemimpin salah satunya adalah komitmen meningkatkan kualitas sumber daya manusia, karena sumber daya manusia (SDM) merupakan faktor penentu dalam kemajuan suatu organisasi, dan pemimpin harus memiliki komitmen yang kuat untuk meningkatkan kualitas SDM.

Hal tersebut menjadikan bahwa kepala sekolah ingin bersama-sama untuk melakukan pengembangan diri demi terwujudnya pendidikan yang efektif yang ditunjukkan dengan tercapainya tujuan dari pendidikan itu sendiri. Jadi Kepala SMPN 18 Malang dan SMPN 11 Malang dapat menciptakan keefektifan dalam kepemimpinan untuk mencapai tujuan yang telah ditentukan.

\section{Keterbukaan terhadap Pelaksanaan Tugas dan Fungsi dalam Pelaksanaan Kepemimpinan di SMPN 11 dan SMPN 18 Malang}

Keterbukaan kepemimpinan merupakan salah satu indikator kepribadian yang baik menurut Sudrajat (dalam Makawimbang, 2012),

Sikap terbuka dalam melaksanakan TUPOKSI ditunjukkan dengan, 1) Cenderung selalu untuk menginformasikan secara profesional dan transparan kepada orang lain atas segala proses pelaksanaan, perencanaan, dan keefektifan, serta menginformasikan kelebihan dan kekurangan pelaksanaan suatu TUPOKSI; 2) Terbuka terhadap saran dan kritik yang disampaikan oleh atasan, bawahan, teman sejawat, dan pihak lain atas pelaksanaan suatu TUPOKSI.

Dalam hal ini keterbukaan yang ditujukkan kepala sekolah dalam hal kepemimpinan yaitu dengan menunjukkan penggunaan dana BOS pada papan pengumuman yang ada di sekolah, selain itu kedua kepala sekolah ini sama-sama terbuka terhadap kritik dan saran yang disampaikan baik secara informal maupun formal.

Kepala sekolah juga menunjukkan keterbukaan dalam hal kepedulian terhadap semua anggota sekolah, dalam bentuk teguran, sindiran maupun pemangilan untuk menghadap kepala sekolah sendiri.

\section{Pengendalikan Diri Kepala Sekolah di SMPN 11 dan SMPN 18 Malang dalam Menghadapi Masalah}

Dalam hal penyelesaian masalah kepala sekolah melalui beberapa tahapan atau alur untuk pemecahan masalah, alur tersebut berguna untuk menghindari kesalahan dalam pengambilan keputusan, serta mendapatkan alternatif terbaik dalam pemecahan masalah. Kepala sekolah kebanyakan melakukan rapat/berdiskusi dengan pihak yang bersangkutan untuk menyelesaikan masalah, tidak pernah kepala sekolah membuat keputusan yang bersifat menguntungkan kehendak pribadi, semua keputusan dirapatkan, kecuali keadaan yang mendesak.

Arief (dalam Lukman, 2016) menjelaskan bahwa etika dan moralitas yang harus dimiliki pemimpin salah satunya adalah kemampuan komunikasi karena suatu proses kepemimpinan pada dasarnya mengandung beberapa komponen yaitu: pemimpin, yang dipimpin, komunikasi dan interaksi antara pemimpin dan yang dipimpin, serta lingkungan dari proses komunikasi tersebut. Jadi dengan adanya komunikasi kesalahpahaman akan terhindar dan semua permasalahan dapat diselesaikan. 


\section{KESIMPULAN}

Akhlak yang dapat diteladani dari kepala sekolah yaitu ramah, sopan, rendah hati, peduli terhadap warga sekolah dan taat beribadah. Selain itu kepala sekolah memiliki integritas sebagai pemimpin pendidikan yang ditunjukkan dengan sikap kejujuran, keadilan, disiplin,dan tanggung jawab yang tinggi terhadap semua bahasan di sekolah, baik terhadap program maupun terhadap warga sekolah. Kepala sekolah dalam pengembangan diri sebagai pemimpin pendidikan dilakukan secara bersama-sama, dengan tujuan terwujudnya pendidikan yang efektif yang ditunjukkan dengan tercapainya tujuan dari pendidikan itu sendiri. Pengembangan diri yang telah dilakukan kepala sekolah yaitu dengan melakukan seminar, pelatihan, tukar pendapat antar kepala sekolah, dan beberapa kegiatan pengembangan diri yang dilakukan secara individu oleh kepala sekolah sendiri, seperti membaca, belajar dari internet dll.

Kepala SMPN 11 dan SMPN 18 Malang menunjukkan keterbukaan terhadap semua TUPOKSI baik dalam bentuk kritikan dan saran, selain itu Kepala SMPN 11 dan SMPN 18 memiliki pengendalian diri sangat baik, terlihat pada saat menghadapi masalah. Kepala sekolah menyelesaikan malasah dengan tenang, tidak gegabah dalam mengambil keputusan, dengan melihat akar permasalahan terlebih dahulu, kemudian ditentukan pemecahannya.

\section{DAFTAR RUJUKAN}

Arifin, I. 2015. Kompetensi Kepribadian Kepala Sekolah Berbasis Moral Spiritual dalam Mengimplementasi Pendidikan Karakter (Online), (http://ap.fip.um.ac.id/wp-content/uploads/2015/04/28-imron-arifinKOMPETENSI-KEPRIBADIAN-KEPALA-SEKOLAH-BERBASIS-MORAL-SPIRITUAL-DALAM.pdf). Diakses pada 2 Maret 2018.

Gunawan, I., dan Benty, D. 2017. Manajemen Pendidikan: Suatu Pengantar Praktik. Bandung: Alfabeta.

Hariyanto, F. 2016. Inilah Kepala Sekolah Terbaik Dalam Evaluasi Kinerja (online), (http://malangkota.go.id/iks) diakses 15 Januari 2017

Hermanto. 2012. Manajemen Kepala Sekolah, (online), http://staffnew.uny.ac.id/upload/132299486/pengabdian/ MANAJEMEN+KEPALA+SEKOLAH.pdf. Diakses pada 16 April 2017.

Jaenudin, U. 2012. Psikologi Kepribadian. Bandung: CV. Pustaka Setia

Lukman, S. H. 2016. Etika dan Moralitas Kepemimpinan Pendidikan (Online), (https://www.linkedin.com/pulse/ etika-dan-moralitas-kepemimpinan-pendidikan-sri-hardianty-hardianty). Diakses pada 12 Oktober 2017.

Peraturan Menteri Pendidikan Nasional Nomor 13 tahun 2007 tentang Standar Kepala Sekolah/Madrasah.

Pradja, J.S. 2012. Psikologi kepribadian. Bandung: Pusaka Setia.

Putri, F dan Surnani. 2012. Kepemimpinan Kepala Sekolah yang Efektif di SMAN Se-Kabupaten Lumajang. Jurnal manajemen pendidikan 23 (5):418-423

Sudharta, V., Mujiati, M., dan Rosidah, A. 2017. School Principal's Leadership Behavior In Psychology Perspective. Advances in Economics, Business and Management Research, 2nd International Conference on Educational Management and Administration (CoEMA 2017), 45 (1): 28-33.

Sugiyono. 2010. Memahami Penelitian Kualitatif. Bandung: Alfabeta.

Suhardiman B. 2012. Studi Pengembangan Kepala Sekolah, Jakarta : Rineka Cipta.

Ulfatin, N. 2013. Metode Penelitian Kualitatif di Bidang Pendidikan. Malang: Fakultas Ilmu Pendidikan Universitas Negeri Malang.

Ulfatin, N. 2015. Metode Penelitian Kualitatif di Bidang Pendidikan: Teori dan Aplikasinya. Malang: Media Nusa Creative.

Yulk, K. 2001 Leadership Organization, (Online), (http://s3.amazonaws.com/academia.edu.documents/26015119/ media-f7b-97-randd-leaders-business-yukl.pdf) diakses 10 Oktober 2016. 